\title{
Association of preoperative plasma suPAR levels with intraoperative sublingual microvascular perfusion in patients undergoing major non- cardiac surgery
}

Athanasios Chalkias $\mathrm{PhD}^{1,2,3}$, Nikolaos Papagiannakis $\mathrm{PhD}^{4}$, Bernd Saugel $\mathrm{MD}^{2,5}$, Moritz Flick $\mathrm{MD}^{5}$, Konstantina Kolonia $\mathrm{MD}^{1}$, Zacharoula Angelopoulou MD , Dimitrios Ragias $\mathrm{MD}^{1}$, Dimitra Papaspyrou $\mathrm{MD}^{1}$, Nicoletta Ntalarizou MD ${ }^{1}$, Aikaterini Bouzia $\mathrm{PhD}^{1}$, Konstantinos Stamoulis $\mathrm{PhD}^{1}$, Aikaterini Kyriakaki $\mathrm{MD}^{1}$, Jesper EugenOlsen $\mathrm{PhD}^{6}$, Eleni Laou $\mathrm{PhD}^{1}$, Eleni Arnaoutoglou $\mathrm{PhD}^{1}$

${ }^{1}$ University of Thessaly, School of Health Sciences, Faculty of Medicine, Department of Anesthesiology, Larisa, Greece

${ }^{2}$ Outcomes Research Consortium, Cleveland, OH 44195, USA

${ }^{3}$ Hellenic Society of Cardiopulmonary Resuscitation, Athens, Greece

4 National and Kapodistrian University of Athens, Medical School, Eginition University Hospital, First Department of Neurology, Athens, Greece

${ }^{5}$ University Medical Center Hamburg-Eppendorf, Center of Anesthesiology and Intensive Care Medicine, Department of Anesthesiology, Hamburg, Germany

${ }^{6}$ Copenhagen University Hospital Hvidovre, Department of Clinical Research, Hvidovre, Denmark

Address for correspondence: Athanasios Chalkias MD, PhD, University Hospital of Larisa, Department of Anesthesiology, 41110 Biopolis, Mezourlo, Larisa, Greece, 


\section{ABSTRACT}

Introduction: The plasma suPAR level has previously been associated with postoperative complications and has been shown to be an independent predictor of coronary microvascular function and flow reserve. We investigated the association between preoperative suPAR levels and intraoperative sublingual microvascular perfusion in patients undergoing elective major non-cardiac surgery.

Methods: This study included 100 patients undergoing major non-cardiac surgery between February 2019 and September 2020. The primary objective was to investigate the association between preoperative suPAR and intraoperative sublingual De Backer score, Consensus Proportion of Perfused Vessels (Consensus PPV), and Consensus PPV (small). Secondary objectives were to investigate the associations between these sublingual microcirculatory variables and (1) complications and (2) mean arterial pressure. EDTA blood was collected before induction of anesthesia and plasma suPAR levels were determined using the suPARnostic ${ }^{\circledR}$ quick triage lateral flow assay. Sublingual microcirculation was monitored with Sidestream DarkField (SDF+) imaging technique at 20 minutes after induction of anesthesia before surgical incision (baseline) and then every 30 minutes until emergence from anesthesia.

Results: A decrease of $0.7 \mathrm{~mm}^{-1}$ in the De Backer score, $2.5 \%$ in the Consensus PPV, and $2.8 \%$ in the Consensus PPV (small) from baseline measurement was observed for every $1 \mathrm{ng} / \mathrm{ml}$ increase of suPAR or 1 additional minute of intraoperative time. De Baker score did not change significantly from baseline $(\mathrm{p}=0.404)$, while Consensus PPV and Consensus PPV (small) decreased significantly from baseline $(\mathrm{p}<0.001$ in both cases). The De Backer score, the Consensus PPV, and the Consensus PPV (small) correlated with postoperative complications. Mean arterial pressure correlated with De 
medRxiv preprint doi: https://doi.org/10.1101/2021.07.03.21259960; this version posted July 5, 2021. The copyright holder for this preprint (which was not certified by peer review) is the author/funder, who has granted medRxiv a license to display the preprint in perpetuity.

All rights reserved. No reuse allowed without permission.

Backer score $(\mathrm{p}=0.487)$ but not with Consensus PPV $(\mathrm{p}=0.506)$ or Consensus PPV (small) $(\mathrm{p}=0.697)$ during the intraoperative period.

Conclusion: Preoperative suPAR levels and prolonged operative duration were associated with intraoperative impairment of sublingual microvascular perfusion in patients undergoing elective major non-cardiac surgery.

Key words: inflammation; suPAR; microcirculation; major surgery; perioperative; outcome 


\section{INTRODUCTION}

The microcirculation is the terminal vascular network of the systemic circulation and is key for oxygen transfer to the parenchymal cells. Our understanding of the microcirculation has evolved over the last decades and it has been shown that the microcirculation can be altered even when systemic hemodynamics are considered normal. ${ }^{1,2}$ Hand-held vital microscopes can be used to observe sublingual microcirculatory alterations at the bedside. The sublingual microcirculation reflects splanchnic microcirculatory perfusion and thus provides physiological insight helping to achieve a more physiological approach to perioperative management. ${ }^{3,4}$

There is evidence suggesting an association between chronic systemic inflammation and impaired microcirculatory perfusion. A prolonged inflammatory response may impair vasomotor function and/or increase the rate of proliferation of blood vessels, eventually reducing capillary perfusion and leading to organ dysfunction. ${ }^{5,6}$ In turn, the inflammation-induced microvascular changes may enhance and sustain the inflammatory response. ${ }^{1,5}$

The soluble form of urokinase plasminogen activator receptor (suPAR) is a marker for systemic inflammation. The specific physiologic role of suPAR is unclear, but its levels in circulation reflect the chronic activation of the inflammatory and immune systems. ${ }^{7,8}$ Compared to C-reactive protein, suPAR is a more stable molecule, which makes it a more reliable biomarker for reflecting the state of chronic immune activation of the patient. ${ }^{9}$ Not only suPAR is implicated in the inflammatory response of several diseases, but it was recently reported that individuals can be also genetically predisposed to higher or lower suPAR levels, which give suPAR a significant prognostic value in physiological or pathological conditions. ${ }^{10}$ 
We have recently shown that the preoperative suPAR levels are highly predictive of postoperative complications in different types of surgical procedures or different risk groups, ${ }^{11}$ but the reasons for this are unknown. Interestingly, the suPAR level has previously been demonstrated to be an independent predictor of coronary microvascular dysfunction in patients with non-obstructive coronary artery disease, with doubling of plasma suPAR being associated with about $30 \%$ decrease in coronary flow reserve and, eventually, with heart disease and worse long-term outcomes. ${ }^{12,13} \mathrm{We}$ hypothesized that chronic systemic inflammation, reflected by preoperative suPAR levels, is associated with impaired intraoperative microvascular perfusion in patients having non-cardiac surgery. To test this hypothesis, we performed a prospective observational study and investigated the association between preoperative suPAR levels and intraoperative sublingual microvascular perfusion in patients undergoing elective major non-cardiac surgery.

\section{METHODS}

\section{Design}

This analysis included 100 patients of a previous prospective observational study conducted in the University Hospital of Larisa, Larisa, Greece, from February 2019 to September $2020{ }^{11}$ Ethical approval for this study was provided by the Ethical Committee of the university hospital of Larisa, Greece (IRB no. 60580). The study was designed in accordance with the declaration of Helsinki and was registered at ClinicalTrials.gov (NCT03851965). Written informed consent was obtained from all patients. 


\section{Study objectives}

The primary objective was to investigate the association between preoperative suPAR and intraoperative sublingual De Backer score, Consensus Proportion of Perfused Vessels (Consensus PPV), and Consensus PPV (small). The De Backer score is based on the principle that density of the vessels is proportional to the number of vessels crossing arbitrary lines. ${ }^{14,15}$ It is calculated as the number of vessels crossing the lines divided by the total length of the lines. In addition, the vessel crossings are checked for flow to calculate Perfused De Backer density. Consensus PPV is then calculated as a percentage ratio of the Perfused De Backer density and De Backer density. These calculations are carried out for all vessels and small (up to 20 microns in diameter) vessels (Consensus PPV (small)). Secondary objectives were to investigate the associations between these sublingual microcirculatory variables and (1) complications and (2) mean arterial pressure (MAP).

\section{Patient eligibility}

Consecutive patients who were scheduled to undergo elective major noncardiac surgery with an expected duration of $\geq 2$ hours under general anesthesia were screened for inclusion. All operative approaches were eligible for inclusion, including open and laparoscopic procedures. Patients fulfilling the following criteria were included: age $\geq 18$ years and American Society of Anesthesiologists' (ASA) physical status I to IV.

We excluded patients with any infection within the previous four weeks; severe liver disease; need for renal replacement therapy; allergies; inflammatory or immune system disorders; asthma; obesity $\left(\mathrm{BMI} \geq 30 \mathrm{~kg} \mathrm{~m}^{-2}\right.$ ); mental disability or severe psychiatric disease; alcohol abuse; connective tissue disease including rheumatoid arthritis, ankylosing spondylitis, and systemic lupus erythematosus. We also excluded 
patients who had previously received an organ transplant; who were treated with steroids, antipsychotic or anti-inflammatory/immunomodulatory medication within the previous three months or with opioids during the past week; and who were involved in another study. Legal incapacity or limited legal capacity were also exclusion criteria.

\section{Anesthetic management}

Induction of anesthesia was in supine position and included i.v. midazolam 0.15-0.35 mg/kg over 20-30 seconds, fentanyl $1 \mu \mathrm{g} / \mathrm{kg}$, ketamine $0.2 \mathrm{mg} / \mathrm{kg}$, propofol $1.5-2 \mathrm{mg} / \mathrm{kg}$, rocuronium $0.6 \mathrm{mg} / \mathrm{kg}$, and a fraction of inspired oxygen of $70 \%$. All drugs were prepared in labelled syringes and induction was achieved by administration of a predetermined i.v. bolus dose considering the patient's weight and/or age. Laryngoscopy and intubation proceeded in a standard fashion, while the position of the endotracheal tube was confirmed by auscultation and capnography/capnometry. The patients were then connected to an automated ventilator (Draeger Perseus A500®; Drägerwerk AG \& Co., Lübeck, Germany) and were ventilated using a lung-protective strategy with tidal volume of $7 \mathrm{~mL} / \mathrm{kg}$, positive end-expiratory pressure of $6-8 \mathrm{cmH}_{2} \mathrm{O}$, and plateau pressures $<30 \mathrm{cmH}_{2} \mathrm{O}$.

Maintenance of general anesthesia initially included desflurane 1.0 MAC with $40 \%$ oxygen and $60 \%$ air. Desflurane was used for maintenance because it produces stable effects on the microcirculation compared to sevoflurane. ${ }^{16}$ Depth of anesthesia (bispectral index-BIS, Covidien, France) was monitored, with the target ranging between 40 and $60 .{ }^{17,18}$ Intraoperative fraction of inspired oxygen was then adjusted to maintain an arterial oxygen partial pressure of $80-100 \mathrm{mmHg}^{19-21}$ and normocapnia was maintained by adjusting the respiratory rate as needed. Normothermia $\left(37{ }^{\circ} \mathrm{C}\right)$ and normoglycemia were maintained during the perioperative period. Vasoactive drugs were administrated, if necessary, to maintain a MAP of $65 \mathrm{mmHg}$ but were not provided 
medRxiv preprint doi: https://doi.org/10.1101/2021.07.03.21259960; this version posted July 5, 2021. The copyright holder for this preprint (which was not certified by peer review) is the author/funder, who has granted medRxiv a license to display the preprint in perpetuity.

All rights reserved. No reuse allowed without permission.

10 minutes prior to or during the assessment of microcirculation. After induction of anesthesia, the patients were allowed to stabilize for 20 minutes. ${ }^{19,21}$

\section{Sampling and laboratory measurements}

Participants underwent sampling of peripheral venous blood immediately after arrival to the operating room before induction of anesthesia. Blood samples drawn from all patients were collected in EDTA tubes and were centrifuged at $3.000 \times \mathrm{g}$ for 1 minute. According to the manufacturer's instructions, there is no detectable impact on plasma suPAR concentration when comparing 1 and 10 minutes of centrifugation. Plasma suPAR levels were then determined using the suPARnostic ${ }^{\circledR}$ Quick Triage lateral flow assay (ViroGates, Denmark). This is an easy-to-use quantitative test that is based on the lateral flow principle. The device consists of a nitrocellulose membrane with two immobilized antibody zones and a running buffer with gold particles. The quantitative results are read within 20 minutes by an optical aLF Reader (Qiagen, Germany). ${ }^{11}$ suPAR levels higher than $5.5 \mathrm{ng} / \mathrm{ml}$ were considered as a clinically important indicator of systemic inflammation. We chose the cut-off of $5.5 \mathrm{ng} / \mathrm{ml}$ as this has been previously used in a study of preoperative suPAR levels and post-operative complications and thus allows for comparison of previous findings. ${ }^{22}$ As the chosen cut-off gave a rather large group above $5.5 \mathrm{ng} / \mathrm{ml}$, we chose a second cut-off at 10 $\mathrm{ng} / \mathrm{ml} .{ }^{11}$ There is no specific rationale for this second cut-off, except that suPAR in double digits is often referred to unusually high levels.

\section{Sublingual microcirculation analysis}

Sublingual microcirculation was monitored using the sidestream dark field (SDF+) imaging technique (Microscan; Microvision Medical BV, Amsterdam, The Netherland). Microscan is equipped with a ring of green light-emitting diodes located 
at the end of a probe using a wavelength of $540 \mathrm{~nm}$ that is absorbed by the hemoglobin contained in red blood cells. ${ }^{15,23}$

Videos from at least five different sites of sublingual microcirculation were recorded. The baseline measurement was performed 20 minutes after induction of general anesthesia before surgical incision and then every 30 minutes until emergence from anesthesia. All videos were recorded by the same investigator and significant efforts were made to avoid pressure and movement artefacts, improve focus and illumination, and clean the sublingual mucosa from saliva and/or blood. Before analysis, all videos were evaluated by two experienced raters according to a modified micro-circulation image quality score (MIQS). ${ }^{24}$ The best three videos from each recording were analysed offline by a blinded investigator with the AVA4.3C Research Software (Microvision Medical, Amsterdam, NL). ${ }^{25,26}$ We used the De Backer score as density score and the Consensus PPV and the Consensus PPV (small) as flow scores. ${ }^{27}$

\section{Assessment of postoperative complications}

We used the Clavien-Dindo Classification to assess postoperative complications, morbidity, and mortality in our patients. ${ }^{28,29}$ The Comprehensive Complication Index (CCI) calculator is an online tool to support the assessment of patients' overall morbidity (https://www.assessurgery.com/clavien-dindoclassification/). The CCI is based on the complication grading by Clavien-Dindo Classification and the overall morbidity is reflected on a scale from 0 (no complication) to 100 (death).

This scoring system offers the advantages of being able to compare results over different time periods within the same institution. ${ }^{28}$ According to related studies, a CCI of 26.2 was set as the cut-off point (equivalent to one grade IIIa complication by the Clavien-Dindo Classification) and patients with complications were divided into a 
high-CCI group (group $\mathrm{A}, \mathrm{CCI} \geq 26.2$ ) and a low-CCI group (group $\mathrm{B}, \mathrm{CCI}<26.2$ ) accordingly. ${ }^{30}$

\section{Data collection, monitoring, and management}

Data analysis was based on predefined data points on a prospective data collection form. The staff was blinded to measurements until the end of the study and all data were analyzed. Clinical monitoring throughout the study was performed to maximize protocol adherence, while an independent Data and Safety Monitoring research staff monitored safety, ethical, and scientific aspects of the study. Data collection included demographics, ASA score, anesthesia variables, general blood count, biochemistry profile, suPAR, and C-reactive protein. Considering that the ASA score is not designed to predict mortality, has known inter-rater variation, and offers at least a moderate predictive ability for mortality in multiple surgical settings, we also included the Modified Frailty Index, POSSUM, and ACS-NSQIP risk scores in our analysis for the purposes of perioperative risk adjustment. ${ }^{31}$

The goal of the clinical data management plan was to provide high-quality data by adopting standardized procedures to minimize the number of errors and missing data, and consequently, to generate an accurate database for analysis. Remote monitoring was performed to signal early aberrant patterns, issues with consistency, credibility, and other anomalies. Any missing and outlier data values were individually revised and completed or corrected whenever possible.

\section{Statistical analysis}

Statistical analysis was performed using R v4.0. Spearman's method was used to correlate microcirculation indices with participants' hemodynamic and clinical characteristics, and morbidity and mortality scores. The Benjamini-Hochberg false discovery rate correction was applied in the resulting $\mathrm{P}$ values to account for the 
medRxiv preprint doi: https://doi.org/10.1101/2021.07.03.21259960; this version posted July 5 , 2021. The copyright holder for this preprint (which was not certified by peer review) is the author/funder, who has granted medRxiv a license to display the preprint in perpetuity.

All rights reserved. No reuse allowed without permission.

multiple numbers of tests. Adjusted p-values less than 0.05 were deemed significant. Linear mixed effects models with Restricted Maximum Likelihood Estimation (REML) were used in order to assess the different effects in microcirculatory indices. LME was used instead of repeated-measures ANOVA, due to the different intra-operative duration between patients and the associated missing values. Three linear mixed models were constructed, for each one of the microcirculatory variables (De Backer score, Consensus PPV, and Consensus PPV (small)), with suPAR and the different time points as fixed factors, and the different subjects (patients) as random factors. Changes in intraoperative sublingual microcirculatory variables were assessed by the second term of the model. We chose to include 100 individuals as we expected that this number could reveal important associations and generate results to be used for sample size estimation in future large-scale studies.

\section{RESULTS}

Overall, 100 patients were included in the study, of whom $68(68 \%)$ were men and $32(32 \%)$ were women, with a median age of 70 years (IQR 62.5-75.5). Demographic and clinical characteristics are shown in Table 1 and Supplementary Table 1.

\section{Association of suPAR with intraoperative sublingual microcirculatory variables}

Elevated levels of preoperative suPAR were associated with a decrease in all intraoperative sublingual microcirculatory variables at all time points. Specifically, we observed a decrease of $0.7 \mathrm{~mm}^{-1}$ in the De Backer score, $2.5 \%$ in the Consensus PPV, and $2.8 \%$ in the Consensus PPV (small) from baseline measurement for every $1 \mathrm{ng} / \mathrm{ml}$ increase of suPAR or 1 additional minute of intraoperative time (Table 2). 
Table 3 and Figure 1 depict the estimated differences between different time points and baseline (30 $\mathrm{min})$. The overall test for differences in microcirculatory variables revealed that De Baker score did not change significantly from baseline ( $\mathrm{p}=0.404$ ), while Consensus PPV and Consensus PPV (small) decreased significantly from baseline ( $\mathrm{p}<0.001$ in both cases) during the intraoperative period (Supplementary Table 2).

\section{Secondary outcomes}

The De Backer score, the Consensus PPV, and the Consensus PPV (small) correlated with CCI and POSSUM risk score (Table 4). Mean arterial pressure correlated with De Backer score during the intraoperative period, but the correlation was weak $(\mathrm{p}=0.487)$. Mean arterial pressure did not correlate with Consensus PPV $(\mathrm{p}=0.506)$ or Consensus PPV (small) $(\mathrm{p}=0.697)$ at any time point during the intraoperative period (Supplementary Figures 1-3, Supplementary Table 3).

\section{DISCUSSION}

In this observational study with patients undergoing elective major non-cardiac surgery, we observed a decrease of $0.7 \mathrm{~mm}^{-1}$ in the De Backer score, $2.5 \%$ in the Consensus PPV, and 2.8\% in the Consensus PPV (small) from baseline measurement for every $1 \mathrm{ng} / \mathrm{ml}$ increase of suPAR or 1 additional minute of intraoperative time. The De Baker score did not change significantly from baseline, while the Consensus PPV and the Consensus PPV (small) decreased significantly from baseline during the intraoperative period. Our findings indicate an association between the level of preoperative systemic inflammation and intraoperative impairment of sublingual 
microvascular perfusion, which may be particularly important during prolonged operation/anesthetic times.

Chronic inflammation is a major problem in the general population due to environmental and lifestyle factors. ${ }^{32}$ The level of chronic inflammation is typically assessed using biomarkers of acute inflammation, such as C-reactive protein, white blood cell counts, or proinflammatory cytokines. However, these are rapidly up- and down-regulated, as their biological function is to tightly control the acute inflammatory response, making their quantification time-sensitive. In recent years, suPAR has been investigated as a more stable biomarker of chronic inflammation, and elevated suPAR is closely linked to accelerated biological ageing, cognitive impairment, and development of inflammation-related diseases. ${ }^{33-35}$ Of note, the higher suPAR level decreases the function of the urokinase plasminogen activator receptor system in endothelial cells and may lead to microcirculatory flow abnormalities. ${ }^{36}$ In the present study, we observed a decrease in the De Backer score, the Consensus PPV, and the Consensus PPV (small) for every $1 \mathrm{ng} / \mathrm{ml}$ increase of preoperative suPAR. To the best of our knowledge, this is the first report of the inverse correlation between chronic systemic inflammation, reflected by increased preoperative suPAR levels, and sublingual microcirculatory variables in perioperative medicine. Interestingly, evidence from other populations show that increasing suPAR levels are associated with a more severe microvascular involvement, ${ }^{12,36}$ which is agreement with our findings.

The induction of an inflammatory response can impair the ability of microvasculature network to coordinate a vasodilatory response in different organs, especially in hypertensive individuals. ${ }^{37}$ suPAR is a selective inhibitor of plasminogen activator induced dilation and inhibits urokinase plasminogen activator-mediated vasodilation without compromising its catalytic activity. ${ }^{38,39}$ Also, inflammation and 
hypoxia/ischemia upregulate urokinase plasminogen activator, which impairs hypercapnic and hypotensive dilation. ${ }^{40,41}$ A diminished microcirculatory blood flow may in turn enhance the inflammatory response, ${ }^{1,5,42}$ forming a dangerous vicious cycle. The crucial point for this seems to be the change of the endothelium from a quiescent into an active state. In patients with chronic inflammation, the endothelium has been activated much earlier than the time of surgery and is associated with elevated suPAR levels. ${ }^{12,43}$ In these individuals, graded changes in venular shear rate even for brief periods elicit progressive recruitment of both rolling and firmly adherent leukocytes. ${ }^{44,45}$ The activated leukocytes cause oxidative and enzymatic degradation of the glycocalyx and further impair microvascular perfusion. ${ }^{46,47}$ All these are consistent with our findings, which indicate a strong association between suPAR and microcirculatory flow impairment.

The evidence suggesting an association between microvascular disease and outcomes after non-cardiac surgery is scarce. In a prospective observational study evaluating the relationship between global oxygen delivery, microcirculatory flow, and tissue oxygenation, impairment of microcirculatory flow was more marked in those patients who developed complications. ${ }^{48}$ Of note, the likelihood of developing a complication increases with increasing operative time, but the exact mechanisms underlying this positive association are not fully understood. ${ }^{49-51}$ We herein report that the De Backer score, the Consensus PPV, and the Consensus PPV (small) were inversely correlated with the CCI and the POSSUM risk score, which is important considering that a further decrease in all microcirculatory variables was observed for every $1 \mathrm{ng} / \mathrm{ml}$ increase of suPAR or 1 additional minute of intraoperative time. The CCI adds information on postoperative morbidity, with particular value following extensive surgery and longer postoperative observation periods, ${ }^{29}$ while the POSSUM is 
calculated preoperatively and has been modified and validated for numerous subtypes of surgeries and clinical scenarios. Given that the sublingual microcirculatory alterations occurring during non-cardiac surgery may be maintained during the immediate and early postoperative period, ${ }^{46,48,52}$ the cumulative effects of chronic inflammation and prolonged operative time on microvascular perfusion are important in the occurrence of postoperative complications.

The impairment of microcirculatory perfusion may be independent of systemic hemodynamics. ${ }^{43,52,53}$ This was also evident in this study, which revealed only a weak correlation between MAP and De Backer score during the intraoperative period. De Backer et al. reported that the microcirculatory perfusion might only deteriorate when MAP is lower than $60-65 \mathrm{mmHg} .{ }^{54,55}$ Maintaining MAP at higher targets may be more effective for improving splanchnic perfusion during surgery, but this may require the use of exogenous vasopressors which increase systemic vascular resistance and may aggravate microcirculatory perfusion. ${ }^{54-56}$ In the present study, intraoperative MAP was maintained $60-120 \mathrm{mmHg}$ and therefore, we can argue that the inflammation-induced uncoupling of systemic and sublingual microcirculatory variables may not be corrected within this MAP range. Further research is necessary to clarify the effects of MAP on sublingual microcirculatory perfusion.

The inclusion of many patients with ASA classifications III and IV allowed to investigate changes of sublingual microcirculatory variables in high-risk patients and their correlation with suPAR. The main limitation is that it is a single-center study and should be reproduced in a multicenter study to improve general applicability. In this study, microcirculatory variables were determined in the sublingual vascular bed. We used the sublingual space as the site of imaging because it shares the same embryologic origin as the splanchnic mucosa and can reflect derangements in splanchnic blood 
medRxiv preprint doi: https://doi.org/10.1101/2021.07.03.21259960; this version posted July 5, 2021. The copyright holder for this preprint (which was not certified by peer review) is the author/funder, who has granted medRxiv a license to display the preprint in perpetuity.

All rights reserved. No reuse allowed without permission.

flow. ${ }^{3,4}$ However, regional sublingual microcirculation may not always reflect regional microcirculation in vital organs. Also, the software used for quantification of sublingual microcirculatory perfusion is not validated at this time. The number of patients may be relatively small for the different types of surgical interventions, while the absence of significant differences for some study variables may be due to the sample size. However, this is one of the largest prospective cohorts investigating the correlation between chronic systemic inflammation and sublingual microcirculatory perfusion in perioperative medicine. Another limitation is that $36 \%$ and $14 \%$ of the patients received $\beta$-blockers and angiotensin-converting enzyme inhibitors, respectively. Nevertheless, both were stopped 24 hours before surgery and thus, their impact is minimal. ${ }^{57}$ Despite the limitations, the present study revealed important associations and results that can be used in future studies.

\section{CONCLUSION}

Preoperative suPAR levels and prolonged operative duration were associated with intraoperative impairment of sublingual microvascular perfusion in patients undergoing elective major non-cardiac surgery. These findings may help identifying patients that may benefit from advanced perioperative care planning. 
medRxiv preprint doi: https://doi.org/10.1101/2021.07.03.21259960; this version posted July 5 , 2021. The copyright holder for this preprint (which was not certified by peer review) is the author/funder, who has granted medRxiv a license to display the preprint in perpetuity.

All rights reserved. No reuse allowed without permission.

\section{Conflicts of interest}

Dr. Jesper Eugen-Olsen is a co-founder, shareholder and CSO of ViroGates A/S and is mentioned inventor on patents on suPAR owned by Copenhagen University Hospital Hvidovre, Denmark. Dr. Bernd Saugel is a consultant for and has received honoraria for giving lectures from Edwards Lifesciences Inc. (Irvine, CA, USA) outside the submitted work. Dr. Bernd Saugel is a consultant for and has received institutional restricted research grants and honoraria for giving lectures from Pulsion Medical Systems SE (Feldkirchen, Germany) outside the submitted work. Dr. Bernd Saugel has received institutional restricted research grants and honoraria for giving lectures from CNSystems Medizintechnik GmbH (Graz, Austria) outside the submitted work. Dr. Bernd Saugel is a consultant for and has received institutional restricted research grants from Retia Medical LLC. (Valhalla, NY, USA) outside the submitted work. Dr. Bernd Saugel is a consultant for and has received honoraria for giving lectures from Philips Medizin Systeme Böblingen GmbH (Böblingen, Germany) outside the submitted work. Dr. Bernd Saugel is a consultant for and has received honoraria for giving lectures from GE Healthcare (Chicago, IL, USA) outside the submitted work. Dr. Bernd Saugel was a consultant for and has received institutional restricted research grants from Tensys Medical Inc. (San Diego, CA, USA) outside the submitted work. Dr. Moritz Flick has received honoraria for consulting and giving lectures from CNSystems Medizintechnik (Graz, Austria) outside the submitted work. All other authors report no conflicts of interest.

\section{Funding}

No funding received. 
medRxiv preprint doi: https://doi.org/10.1101/2021.07.03.21259960; this version posted July 5 , 2021. The copyright holder for this preprint (which was not certified by peer review) is the author/funder, who has granted medRxiv a license to display the preprint in perpetuity.

All rights reserved. No reuse allowed without permission.

\section{Data sharing}

Data from SPARSE can be made available upon request through a collaborative process. Please contact the corresponding author for additional information.

\section{Acknowledgements}

This research was partially supported by the Hellenic Society of Cardiopulmonary Resuscitation, Athens, Greece. The authors would like to thank the medical and nursing stuff of the Department of Anesthesiology, University Hospital of Larisa, for their assistance during the study period. We are also thankful to Z. Hossain, medical software engineer at Microvision Medical (Amsterdam, The Netherlands), who provided expertise that greatly assisted the research.

\section{Author Contributions}

Dr. Athanasios Chalkias designed the study. Dr. Athanasios Chalkias, Dr. Konstantina Kolonia, Dr. Zacharoula Angelopoulou, Dr. Dimitrios Ragias, Dr. Dimitra Papaspyrou, Dr. Nicoletta Ntalarizou, Dr. Aikaterini Bouzia, Dr. Konstantinos Stamoulis, Dr. Aikaterini Kyriakaki, Dr. Eleni Laou, and Dr. Eleni Arnaoutoglou collected the data and performed quality control. Dr. Athanasios Chalkias, Dr. Nikolaos Papagiannakis, and Dr. Eleni Laou analyzed the data. Dr. Athanasios Chalkias, Dr. Bernd Saugel, Dr. Moritz Flick, and Dr. Jesper Eugen-Olsen interpreted the results. Dr. Athanasios Chalkias wrote the first draft of the manuscript. All coauthors provided critical revisions to the manuscript. All authors approved the final version of the manuscript. 


\section{REFERENCES}

1. Guven G, Hilty MP, Ince C. Microcirculation: Physiology, Pathophysiology, and Clinical Application. Blood Purif. 2020;49(1-2):143-150.

2. Jung C. Assessment of microcirculation in cardiogenic shock. Curr Opin Crit Care. 2019;25(4):410-6.

3. Bouattour K, Teboul JL, Varin L, Vicaut E, Duranteau J. Preload Dependence Is Associated with Reduced Sublingual Microcirculation during Major Abdominal Surgery. Anesthesiology. 2019 Apr;130(4):541-549.

4. Bansch P, Flisberg P, Bentzer P. Changes in the sublingual microcirculation during major abdominal surgery and post-operative morbidity. Acta Anaesthesiol Scand. 2014 Jan;58(1):89-97.

5. Granger DN, Senchenkova E. Inflammation and the Microcirculation. In: Granger DN, Granger JP (eds). Colloquium Series on Integrated Systems Physiology: from Molecule to Function to Disease. Morgan \& Claypool 2010;165.

6. Medzhitov R. Origin and physiological roles of inflammation. Nature. $2008 \mathrm{Jul}$ $24 ; 454(7203): 428-35$.

7. Azam TU, Shadid HR, Blakely P, O'Hayer P, Berlin H, Pan M, Zhao P, Zhao L, Pennathur S, Pop-Busui R, Altintas I, Tingleff J, Stauning MA, Andersen O, Adami ME, Solomonidi N, Tsilika M, Tober-Lau P, Arnaoutoglou E, Keitel V, Tacke F, Chalkias A, Loosen SH, Giamarellos-Bourboulis EJ, Eugen-Olsen J, Reiser J, Hayek SS; International Study of Inflammation in COVID-19. Soluble Urokinase Receptor (SuPAR) in COVID-19-Related AKI. J Am Soc Nephrol. 2020 Nov;31(11):2725-2735. 
8. Gozdzik W, Adamik B, Gozdzik A, Rachwalik M, Kustrzycki W, Kübler A. Unchanged plasma levels of the soluble urokinase plasminogen activator receptor in elective coronary artery bypass graft surgery patients and cardiopulmonary bypass use. PLoS One. 2014 Jun 9;9(6):e98923.

9. Riisbro R, Christensen IJ, Høgdall C, Brünner N, Høgdall E. Soluble urokinase plasminogen activator receptor measurements: influence of sample handling. Int J Biol Markers. 2001 Oct-Dec;16(4):233-9.

10. Dowsett J, Ferkingstad E, Rasmussen LJH, Thørner LW, Magnússon MK, Sugden K, Thorleifsson G, Frigge M, Burgdorf KS, Ostrowski SR, Sørensen E, Erikstrup C, Pedersen OB, Hansen TF, Banasik K, Brunak S; DBDS Genomic Consortium, Tragante V, Lund SH, Stefansdottir L, Gunnarson B, Poulton R, Arseneault L, Caspi A, Moffitt TE, Gudbjartsson D, Eugen-Olsen J, Stefánsson H, Stefánsson K, Ullum H. Eleven genomic loci affect plasma levels of chronic inflammation marker soluble urokinase-type plasminogen activator receptor. Commun Biol. 2021 Jun 2;4(1):655.

11. Chalkias A, Laou E, Kolonia K, Ragias D, Angelopoulou Z, Mitsiouli E, Kallemose T, Smith-Hansen L, Eugen-Olsen J, Arnaoutoglou E. Elevated preoperative suPAR is a strong and independent risk marker for postoperative complications in high-risk patients undergoing major non-cardiac surgery (SPARSE). $\quad$ medRxiv 2021.05.04.21256448; doi: https://doi.org/10.1101/2021.05.04.21256448.

12. Mekonnen G, Corban MT, Hung OY, Eshtehardi P, Eapen DJ, Al-Kassem H, Rasoul-Arzrumly E, Gogas BD, McDaniel MC, Pielak T, Thorball CW, Sperling L, Quyyumi AA, Samady H. Plasma soluble urokinase-type plasminogen activator receptor level is independently associated with coronary 
microvascular function in patients with non-obstructive coronary artery disease. Atherosclerosis. 2015 Mar;239(1):55-60.

13. Nakanishi K, Fukuda S, Shimada K, Miyazaki C, Otsuka K, Maeda K, Miyahana R, Kawarabayashi T, Watanabe H, Yoshikawa J, Yoshiyama M. Impaired coronary flow reserve as a marker of microvascular dysfunction to predict long-term cardiovascular outcomes, acute coronary syndrome and the development of heart failure. Circ J. 2012;76(8):1958-64.

14. De Backer D, Hollenberg S, Boerma C, Goedhart P, Büchele G, Ospina-Tascon G, Dobbe I, Ince C. How to evaluate the microcirculation: report of a round table conference. Crit Care. 2007;11(5):R101.

15. Massey MJ, Shapiro NI. A guide to human in vivo microcirculatory flow image analysis. Crit Care. 2016 Feb 10;20:35.

16. Özarslan NG, Ayhan B, Kanbak M, Çelebioğlu B, Demircin M, Ince C, Aypar Ü: Comparison of the effects of sevoflurane, isoflurane, and desflurane on microcirculation in coronary artery bypass graft surgery. J Cardiothorac Vasc Anesth 26(5):791-798, 2012.

17. Kertai MD, White WD, Gan TJ. Cumulative duration of "triple low" state of low blood pressure, low bispectral index, and low minimum alveolar concentration of volatile anesthesia is not associated with increased mortality. Anesthesiology. 2014 Jul;121(1):18-28.

18. Willingham M, Ben Abdallah A, Gradwohl S, Helsten D, Lin N, Villafranca A, Jacobsohn E, Avidan M, Kaiser H. Association between intraoperative electroencephalographic suppression and postoperative mortality. Br J Anaesth. 2014 Dec;113(6):1001-8. 
19. Milstein DM, Helmers R, Hackmann S, Belterman CN, van Hulst RA, de Lange J. Sublingual microvascular perfusion is altered during normobaric and hyperbaric hyperoxia. Microvasc Res. 2016 May;105:93-102.

20. Schwarte LA, Schober P, Loer SA. Benefits and harms of increased inspiratory oxygen concentrations. Curr Opin Anaesthesiol. 2019 Dec;32(6):783-791.

21. Orbegozo Cortés D, Puflea F, Donadello K, Taccone FS, Gottin L, Creteur J, Vincent JL, De Backer D. Normobaric hyperoxia alters the microcirculation in healthy volunteers. Microvasc Res. 2015 Mar;98:23-8.

22. Alstrup M, Meyer J, Schultz M, Rasmussen LJH, Rasmussen LS, Køber L, Forberg JL, Eugen-Olsen J, Iversen K. Soluble Urokinase Plasminogen Activator Receptor (suPAR) as an Added Predictor to Existing Preoperative Risk Assessments. World J Surg. 2019 Mar;43(3):780-790.

23. Donati A, Damiani E, Luchetti M, Domizi R, Scorcella C, Carsetti A, Gabbanelli V, Carletti P, Bencivenga R, Vink H, Adrario E, Piagnerelli M, Gabrielli A, Pelaia P, Ince C. Microcirculatory effects of the transfusion of leukodepleted or non-leukodepleted red blood cells in patients with sepsis: a pilot study. Crit Care. 2014 Feb 17;18(1):R33.

24. Massey MJ, Larochelle E, Najarro G, Karmacharla A, Arnold R, Trzeciak S, Angus DC, Shapiro NI. The microcirculation image quality score: development and preliminary evaluation of a proposed approach to grading quality of image acquisition for bedside videomicroscopy. J Crit Care. 2013 Dec;28(6):913-7.

25. Dobbe JG, Streekstra GJ, Atasever B, van Zijderveld R, Ince C. Measurement of functional microcirculatory geometry and velocity distributions using automated image analysis. Med Biol Eng Comput. 2008 Jul;46(7):659-70. 
26. Ince C, Boerma EC, Cecconi M, De Backer D, Shapiro NI, Duranteau J, Pinsky MR, Artigas A, Teboul JL, Reiss IKM, Aldecoa C, Hutchings SD, Donati A, Maggiorini M, Taccone FS, Hernandez G, Payen D, Tibboel D, Martin DS, Zarbock A, Monnet X, Dubin A, Bakker J, Vincent JL, Scheeren TWL; Cardiovascular Dynamics Section of the ESICM. Second consensus on the assessment of sublingual microcirculation in critically ill patients: results from a task force of the European Society of Intensive Care Medicine. Intensive Care Med. 2018 Mar;44(3):281-299.

27. De Backer D, Creteur J, Preiser JC, Dubois MJ, Vincent JL. Microvascular blood flow is altered in patients with sepsis. Am J Respir Crit Care Med. 2002 Jul 1;166(1):98-104.

28. Bolliger M, Kroehnert JA, Molineus F, Kandioler D, Schindl M, Riss P. Experiences with the standardized classification of surgical complications (Clavien-Dindo) in general surgery patients. Eur Surg. 2018;50(6):256-261.

29. Clavien PA, Vetter D, Staiger RD, Slankamenac K, Mehra T, Graf R, Puhan MA. The Comprehensive Complication Index $\left(\mathrm{CCI}{ }^{\circledR}\right)$ : Added Value and Clinical Perspectives 3 Years "Down the Line". Ann Surg. 2017 Jun;265(6):1045-1050.

30. Tu RH, Lin JX, Li P, Xie JW, Wang JB, Lu J, Chen QY, Cao LL, Lin M, Zheng $\mathrm{CH}$, Huang CM. Comprehensive Complication Index Predicts Cancer-Specific Survival of Patients with Postoperative Complications after Curative Resection of Gastric Cancer. Gastroenterol Res Pract. 2018 Nov 19;2018:4396018.

31. De Hert S, Staender S, Fritsch G, Hinkelbein J, Afshari A, Bettelli G, Bock M, Chew MS, Coburn M, De Robertis E, Drinhaus H, Feldheiser A, Geldner G, Lahner D, Macas A, Neuhaus C, Rauch S, Santos-Ampuero MA, Solca M, 
Tanha N, Traskaite V, Wagner G, Wappler F. Pre-operative evaluation of adults undergoing elective noncardiac surgery: Updated guideline from the European Society of Anaesthesiology. Eur J Anaesthesiol. 2018 Jun;35(6):407-465.

32. Pietzner M, Kaul A, Henning AK, Kastenmüller G, Artati A, Lerch MM, Adamski J, Nauck M, Friedrich N. Comprehensive metabolic profiling of chronic low-grade inflammation among generally healthy individuals. BMC Med. 2017 Nov 30;15(1):210.

33. Rasmussen LJH, Caspi A, Ambler A, Danese A, Elliott M, Eugen-Olsen J, Hariri AR, Harrington H, Houts R, Poulton R, Ramrakha S, Sugden K, Williams B, Moffitt TE. Association Between Elevated suPAR, a New Biomarker of Inflammation, and Accelerated Aging. J Gerontol A Biol Sci Med Sci. 2021 Jan $18 ; 76(2): 318-327$.

34. Eugen-Olsen J, Andersen O, Linneberg A, Ladelund S, Hansen TW, Langkilde A, Petersen J, Pielak T, Møller LN, Jeppesen J, Lyngbaek S, Fenger M, Olsen MH, Hildebrandt PR, Borch-Johnsen K, Jørgensen T, Haugaard SB. Circulating soluble urokinase plasminogen activator receptor predicts cancer, cardiovascular disease, diabetes and mortality in the general population. J Intern Med. 2010 Sep;268(3):296-308.

35. Hayek SS, Sever S, Ko YA, Trachtman H, Awad M, Wadhwani S, Altintas MM, Wei C, Hotton AL, French AL, Sperling LS, Lerakis S, Quyyumi AA, Reiser J. Soluble Urokinase Receptor and Chronic Kidney Disease. N Engl J Med. 2015 Nov 12;373(20):1916-25.

36. Legány N, Toldi G, Distler JH, Beyer C, Szalay B, Kovács L, Vásárhelyi B, Balog A. Increased plasma soluble urokinase plasminogen activator receptor levels in systemic sclerosis: possible association with microvascular 
abnormalities and extent of fibrosis. Clin Chem Lab Med. 2015 Oct;53(11):1799-805.

37. Payne GW. Effect of inflammation on the aging microcirculation: impact on skeletal muscle blood flow control. Microcirculation. 2006 Jun;13(4):343-52.

38. Armstead WM, Cines DB, Higazie AA. Plasminogen activators contribute to age-dependent impairment of NMDA cerebrovasodilation after brain injury. Brain Res Dev Brain Res. 2005 May 12;156(2):139-46.

39. Armstead WM, Cines DB, Bdeir K, Kulikovskaya I, Stein SC, Higazi AA. uPA impairs cerebrovasodilation after hypoxia/ischemia through LRP and ERK MAPK. Brain Res. 2008 Sep 22;1231:121-31.

40. Farris SD, Hu JH, Krishnan R, Emery I, Chu T, Du L, Kremen M, Dichek HL, Gold E, Ramsey SA, Dichek DA. Mechanisms of urokinase plasminogen activator (uPA)-mediated atherosclerosis: role of the uPA receptor and S100A8/A9 proteins. J Biol Chem. 2011 Jun 24;286(25):22665-77.

41. Nassar T, Yarovoi S, Fanne RA, Waked O, Allen TC, Idell S, Cines DB, Higazi AA. Urokinase plasminogen activator regulates pulmonary arterial contractility and vascular permeability in mice. Am J Respir Cell Mol Biol. 2011 Nov;45(5):1015-21.

42. Uz Z, Ince C, Shen L, Ergin B, van Gulik TM. Real-time observation of microcirculatory leukocytes in patients undergoing major liver resection. Sci Rep. 2021 Feb 25;11(1):4563.

43. Schier R, Zimmer P, Riedel B. Perioperative Inflammation and Microcirculation in Surgery: Clinical Strategies for Improved Surgical Outcomes. In: Lenasi H (ed). Microcirculation Revisited. From Molecules to Clinical Practice. IntechOpen 2016;259-276. 
44. Takeishi N, Imai Y, Nakaaki K, Yamaguchi T, Ishikawa T. Leukocyte margination at arteriole shear rate. Physiol Rep. 2014 Jun 6;2(6):e12037.

45. Bienvenu K, Russell J, Granger DN. Leukotriene B4 mediates shear ratedependent leukocyte adhesion in mesenteric venules. Circ Res. 1992 Oct;71(4):906-11.

46. Chalkias A, Papagiannakis N, Mavrovounis G, Kolonia K, Mermiri M, Pantazopoulos I, Laou E, Arnaoutoglou E. Sublingual microcirculatory alterations during the immediate and early postoperative period: A systematic review and meta-analysis. medRxiv 2021. doi: https://doi.org/10.1101/2021.04.03.21254867.

47. Becker BF, Jacob M, Leipert S, Salmon AH, Chappell D. Degradation of the endothelial glycocalyx in clinical settings: searching for the sheddases. Br J Clin Pharmacol. 2015 Sep;80(3):389-402.

48. Jhanji S, Lee C, Watson D, Hinds C, Pearse RM. Microvascular flow and tissue oxygenation after major abdominal surgery: association with post-operative complications. Intensive Care Med. 2009 Apr;35(4):671-7.

49. Cheng H, Clymer JW, Po-Han Chen B, Sadeghirad B, Ferko NC, Cameron CG, Hinoul P. Prolonged operative duration is associated with complications: a systematic review and meta-analysis. J Surg Res. 2018 Sep;229:134-144.

50. Cheng H, Chen BP, Soleas IM, Ferko NC, Cameron CG, Hinoul P. Prolonged Operative Duration Increases Risk of Surgical Site Infections: A Systematic Review. Surg Infect (Larchmt). 2017 Aug/Sep;18(6):722-735.

51. Dąbrowska AM, Słotwiński R. The immune response to surgery and infection. Cent Eur J Immunol. 2014;39(4):532-7. 
medRxiv preprint doi: https://doi.org/10.1101/2021.07.03.21259960; this version posted July 5 , 2021. The copyright holder for this preprint (which was not certified by peer review) is the author/funder, who has granted medRxiv a license to display the preprint in perpetuity.

All rights reserved. No reuse allowed without permission.

52. Smilowitz NR, Redel-Traub G, Berger JS. Microvascular Disease and Perioperative Outcomes of Non-Cardiac Surgery. Am J Cardiol. 2021 Jan $15 ; 139: 121-125$.

53. Stens J, de Wolf SP, van der Zwan RJ, Koning NJ, Dekker NA, Hering JP, Boer C. Microcirculatory perfusion during different perioperative hemodynamic strategies. Microcirculation. 2015 May;22(4):267-75.

54. De Backer D, Ortiz JA, Salgado D. Coupling microcirculation to systemic hemodynamics. Curr Opin Crit Care. 2010 Jun;16(3):250-4.

55. De Backer D, Donadello K, Taccone FS, Ospina-Tascon G, Salgado D, Vincent JL. Microcirculatory alterations: potential mechanisms and implications for therapy. Ann Intensive Care. 2011 Jul 19;1(1):27.

56. De Backer D, Foulon P. Minimizing catecholamines and optimizing perfusion. Crit Care. 2019 Jun 14;23(Suppl 1):149.

57. Blessberger H, Lewis SR, Pritchard MW, Fawcett LJ, Domanovits H, Schlager O, Wildner B, Kammler J, Steinwender C. Perioperative beta-blockers for preventing surgery-related mortality and morbidity in adults undergoing noncardiac surgery. Cochrane Database Syst Rev. 2019 Sep 26;9(9):CD013438. 


\section{FIGURES}
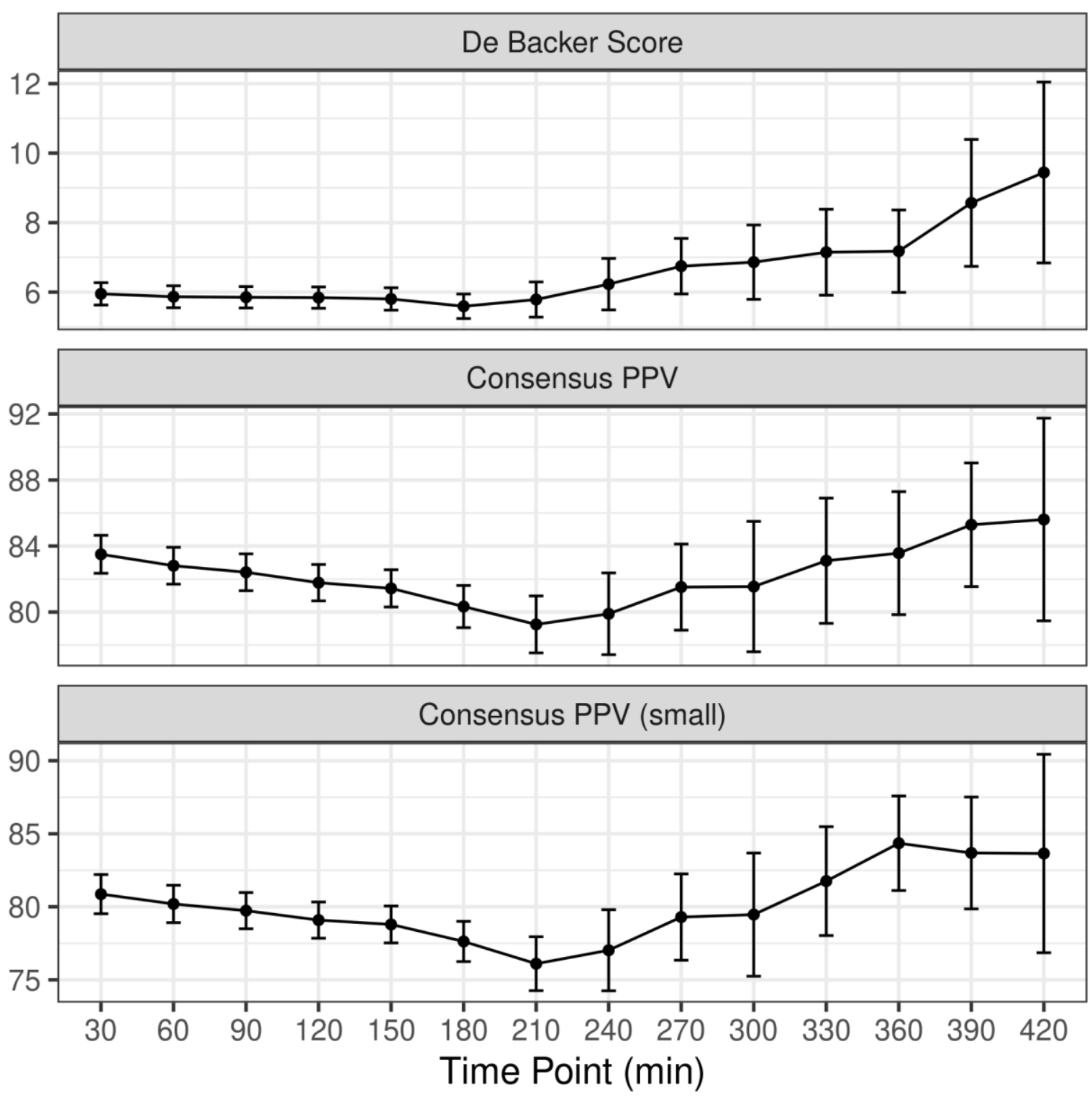

Figure 1. Change in De Backer score $\left(\mathrm{mm}^{-1}\right)$, Consensus PPV (\%), and Consensus PPV (small) $(\%)$ with time. 
medRxiv preprint doi: https://doi.org/10.1101/2021.07.03.21259960; this version posted July 5, 2021. The copyright holder for this preprint (which was not certified by peer review) is the author/funder, who has granted medRxiv a license to display the preprint in perpetuity.

All rights reserved. No reuse allowed without permission.

\section{TABLES}

Table 1. Demographic and clinical characteristics of patients undergoing major non-cardiac surgery

\begin{tabular}{|c|c|c|}
\hline Age, years (mean \pm std deviation) & & $67.2 \pm 12.5$ \\
\hline Sex (Male), n (\%) & & $68(68 \%)$ \\
\hline \multirow[t]{3}{*}{ ASA class, $\mathrm{n}(\%)$} & II & $17(17 \%)$ \\
\hline & III & $43(43 \%)$ \\
\hline & IV & $40(40 \%)$ \\
\hline \multirow[t]{8}{*}{ Type of surgery, n (\%) } & Endocrinological & $1(1 \%)$ \\
\hline & Gastrointestinal & $42(42 \%)$ \\
\hline & Gastrointestinal / Gynecological & $1(1 \%)$ \\
\hline & Gynecological & $5(5 \%)$ \\
\hline & Thoracic & $1(1 \%)$ \\
\hline & Urological & $16(16 \%)$ \\
\hline & Vascular & $32(32 \%)$ \\
\hline & Various & $2(2 \%)$ \\
\hline \multicolumn{3}{|l|}{ Medication } \\
\hline \multirow{2}{*}{ Aspirin, n (\%) } & No & $74(74 \%)$ \\
\hline & Yes & $26(26 \%)$ \\
\hline \multirow[t]{2}{*}{ Beta blocker, n (\%) } & No & $64(64 \%)$ \\
\hline & Yes & $36(36 \%)$ \\
\hline \multirow[t]{2}{*}{ ACEi, n (\%) } & No & $86(86 \%)$ \\
\hline & Yes & $14(14 \%)$ \\
\hline \multirow[t]{2}{*}{ Diuretic, n (\%) } & No & $78(78 \%)$ \\
\hline & Yes & $22(22 \%)$ \\
\hline \multicolumn{3}{|l|}{ Comorbidities } \\
\hline \multirow[t]{2}{*}{ Ischemic heart disease, $\mathrm{n}(\%)$} & No & $78(78 \%)$ \\
\hline & Yes & $22(22 \%)$ \\
\hline \multirow[t]{2}{*}{ Arterial hypertension, n (\%) } & No & $36(36 \%)$ \\
\hline & Yes & $64(64 \%)$ \\
\hline \multirow[t]{2}{*}{ Hypercholesterolemia, n (\%) } & No & $51(51 \%)$ \\
\hline & Yes & $49(49 \%)$ \\
\hline \multirow[t]{2}{*}{ Diabetes, n (\%) } & No & $86(86 \%)$ \\
\hline & Yes & $14(14 \%)$ \\
\hline \multirow[t]{2}{*}{ Stroke, n (\%) } & No & $93(93 \%)$ \\
\hline & Yes & $7(7 \%)$ \\
\hline \multirow[t]{2}{*}{ COPD, n (\%) } & No & $76(76 \%)$ \\
\hline & Yes & $24(24 \%)$ \\
\hline \multirow[t]{2}{*}{ Asthma, n (\%) } & No & $98(98 \%)$ \\
\hline & Yes & $2(2 \%)$ \\
\hline \multirow[t]{2}{*}{ Other, n (\%) } & No & $37(37 \%)$ \\
\hline & Yes & $63(63 \%)$ \\
\hline
\end{tabular}


medRxiv preprint doi: https://doi.org/10.1101/2021.07.03.21259960; this version posted July 5, 2021. The copyright holder for this preprint (which was not certified by peer review) is the author/funder, who has granted medRxiv a license to display the preprint in perpetuity.

All rights reserved. No reuse allowed without permission.

Table 2. Association of suPAR with intraoperative sublingual microcirculatory perfusion

\begin{tabular}{lccc}
\hline & Beta coefficient $^{\text {a }}$ & Standard Error & p-value \\
\hline De Baker score & & & \\
suPAR & -0.716 & 0.041 & $<0.001$ \\
Time (min) & 0.0004 & 0.0004 & 0.405 \\
\hline Consensus PPV & -2.490 & 0.159 & $<0.001$ \\
suPAR & -0.011 & 0.002 & $<0.001$ \\
Time (min) & & \\
Consensus PPV (small) & -2.835 & 0.1713 & $<0.001$ \\
suPAR & -0.0102 & 0.0019 & $<0.001$ \\
Time (min) & & \\
${ }^{a}$ Represents the increase/decrease in the respective microcirculatory variable for every $1 \mathrm{ng} / \mathrm{ml}$ \\
increase of suPAR or 1 additional minute of intraoperative time.
\end{tabular}


medRxiv preprint doi: https://doi.org/10.1101/2021.07.03.21259960; this version posted July 5,2021 . The copyright holder for this preprint (which was not certified by peer review) is the author/funder, who has granted medRxiv a license to display the preprint in perpetuity.

All rights reserved. No reuse allowed without permission.

Table 3. Estimated differences between different intraoperative time points and baseline ( $30 \mathrm{~min})$

\begin{tabular}{|c|c|c|c|c|}
\hline Variable & Time Point & Coefficient $^{\mathrm{a}}$ & Standard Error & p-value ${ }^{a}$ \\
\hline \multirow{14}{*}{ De Baker score } & $30 \mathrm{~min}$ & - & - & - \\
\hline & $60 \mathrm{~min}$ & -0.0842 & 0.1283 & 0.512 \\
\hline & $90 \mathrm{~min}$ & -0.0978 & 0.1283 & 0.446 \\
\hline & $120 \mathrm{~min}$ & -0.1084 & 0.1287 & 0.398 \\
\hline & $150 \mathrm{~min}$ & -0.1082 & 0.1299 & 0.405 \\
\hline & $180 \mathrm{~min}$ & -0.0628 & 0.1424 & 0.659 \\
\hline & $210 \mathrm{~min}$ & -0.0357 & 0.1424 & 0.826 \\
\hline & $240 \mathrm{~min}$ & 0.1787 & 0.2049 & 0.384 \\
\hline & $270 \mathrm{~min}$ & 0.1270 & 0.2230 & 0.569 \\
\hline & $300 \mathrm{~min}$ & -0.2128 & 0.2903 & 0.464 \\
\hline & $330 \mathrm{~min}$ & -0.5042 & 0.349 & 0.149 \\
\hline & $360 \mathrm{~min}$ & -0.4742 & 0.349 & 0.175 \\
\hline & $390 \mathrm{~min}$ & -0.5727 & 0.4827 & 0.236 \\
\hline & $420 \mathrm{~min}$ & -0.8235 & 0.5538 & 0.138 \\
\hline \multirow{14}{*}{ Consensus PPV } & $30 \mathrm{~min}$ & - & - & - \\
\hline & $60 \mathrm{~min}$ & -0.6921 & 0.4587 & 0.131 \\
\hline & $90 \mathrm{~min}$ & -1.0881 & 0.4587 & 0.018 \\
\hline & $120 \mathrm{~min}$ & -1.7211 & 0.4587 & 0.000 \\
\hline & $150 \mathrm{~min}$ & -1.8050 & 0.4646 & 0.000 \\
\hline & $180 \mathrm{~min}$ & -2.2 & 0.5091 & 0.000 \\
\hline & $210 \mathrm{~min}$ & -3.1297 & 0.5819 & 0.000 \\
\hline & $240 \mathrm{~min}$ & -1.7432 & 0.7332 & 0.017 \\
\hline & $270 \mathrm{~min}$ & -1.3991 & 0.7979 & 0.080 \\
\hline & $300 \mathrm{~min}$ & -3.0818 & 1.0382 & 0.003 \\
\hline & $330 \mathrm{~min}$ & -3.5306 & 1.2485 & 0.004 \\
\hline & $360 \mathrm{~min}$ & -3.0706 & 1.2485 & 0.014 \\
\hline & $390 \mathrm{~min}$ & -3.3680 & 1.7265 & 0.051 \\
\hline & $420 \mathrm{~min}$ & -5.4735 & 1.9808 & 0.005 \\
\hline \multirow{11}{*}{ Consensus PPV (small) } & $30 \mathrm{~min}$ & - & - & - \\
\hline & $60 \mathrm{~min}$ & -0.6729 & 0.5178 & 0.194 \\
\hline & $90 \mathrm{~min}$ & -1.1324 & 0.5178 & 0.029 \\
\hline & $120 \mathrm{~min}$ & -1.7783 & 0.5178 & 0.001 \\
\hline & $150 \mathrm{~min}$ & -1.7674 & 0.5244 & 0.002 \\
\hline & $180 \mathrm{~min}$ & -2.0482 & 0.5747 & 0.017 \\
\hline & $210 \mathrm{~min}$ & -3.5474 & 0.6568 & 0.118 \\
\hline & $240 \mathrm{~min}$ & -1.9877 & 0.8274 & 0.007 \\
\hline & $270 \mathrm{~min}$ & -1.4105 & 0.9005 & 0.021 \\
\hline & $300 \mathrm{~min}$ & -3.1522 & 1.1717 & 0.635 \\
\hline & $330 \mathrm{~min}$ & -3.2610 & 1.4091 & 0.106 \\
\hline
\end{tabular}


medRxiv preprint doi: https://doi.org/10.1101/2021.07.03.21259960; this version posted July 5, 2021. The copyright holder for this preprint (which was not certified by peer review) is the author/funder, who has granted medRxiv a license to display the preprint in perpetuity.

All rights reserved. No reuse allowed without permission.

\begin{tabular}{|l|l|l|l|l|}
\hline \multirow{2}{*}{} & $360 \mathrm{~min}$ & -0.6697 & 1.4091 & 0.011 \\
\cline { 2 - 5 } & $390 \mathrm{~min}$ & -3.1560 & 1.9486 & 0.106 \\
\cline { 2 - 5 } & $420 \mathrm{~min}$ & -5.6943 & 2.2356 & 0.011 \\
\hline
\end{tabular}

${ }^{a}$ Coefficients and p-values are computed for the difference between each time point and the 30 -min time point, which is considered the reference category. 
medRxiv preprint doi: https://doi.org/10.1101/2021.07.03.21259960; this version posted July 5, 2021. The copyright holder for this preprint (which was not certified by peer review) is the author/funder, who has granted medRxiv a license to display the preprint in perpetuity.

All rights reserved. No reuse allowed without permission.

Table 4. Correlation of microcirculation variables with morbidity and mortality scores

\section{Preoperatively}

\begin{tabular}{|l|l|c|c|}
\hline \multicolumn{2}{|l}{} & Spearman's rho & Adjusted p-value \\
\hline \multirow{5}{*}{ De Backer score } & Modified Frailty Index & -0.156 & 0.12 \\
\cline { 2 - 4 } & POSSUM morbidity score & -0.224 & $\mathbf{0 . 0 2 5}$ \\
\cline { 2 - 4 } & POSSUM mortality score & -0.226 & $\mathbf{0 . 0 2 4}$ \\
\cline { 2 - 4 } & ACS-NSQIP score & -0.144 & 0.153 \\
\cline { 2 - 4 } & ACS-NSQIP excess score & -0.000267 & 0.998 \\
\cline { 2 - 4 } & Comprehensive Complication Index & -0.251 & $\mathbf{0 . 0 1 2}$ \\
\hline \multirow{5}{*}{ Consensus PPV (\%) } & Modified Frailty Index & -0.102 & 0.315 \\
\cline { 2 - 4 } & POSSUM morbidity score & -0.26 & $\mathbf{0 . 0 0 9}$ \\
\cline { 2 - 4 } & POSSUM mortality score & -0.257 & $\mathbf{0 . 0 1}$ \\
\cline { 2 - 4 } & ACS-NSQIP score & -0.149 & 0.138 \\
\cline { 2 - 4 } & ACS-NSQIP excess score & 0.024 & 0.816 \\
\cline { 2 - 4 } & Comprehensive Complication Index & -0.28 & $\mathbf{0 . 0 0 5}$ \\
\hline Consensus PPV (small) (\%) & Modified Frailty Index & -0.075 & 0.456 \\
\cline { 2 - 4 } & POSSUM morbidity score & -0.223 & $\mathbf{0 . 0 2 5}$ \\
\cline { 2 - 4 } & POSSUM mortality score & -0.222 & $\mathbf{0 . 0 2 7}$ \\
\cline { 2 - 4 } & ACS-NSQIP score & -0.179 & $\mathbf{0 . 0 7 4}$ \\
\cline { 2 - 4 } & ACS-NSQIP excess score & 0.031 & 0.759 \\
\cline { 2 - 4 } & Comprehensive Complication Index & -0.277 & $\mathbf{0 . 0 0 5}$ \\
\hline
\end{tabular}

\section{Postoperatively}

De Backer score

Consensus PPV (\%)

Consensus PPV (small) $(\%)$

\begin{tabular}{|l|c|c|} 
& Spearman's rho & Adjusted p-value \\
\hline Modified Frailty Index & -0.184 & 0.067 \\
\hline POSSUM morbidity score & -0.262 & $\mathbf{0 . 0 0 9}$ \\
\hline POSSUM mortality score & -0.265 & $\mathbf{0 . 0 0 8}$ \\
\hline ACS-NSQIP score & -0.141 & 0.162 \\
\hline ACS-NSQIP excess score & -0.121 & 0.232 \\
\hline Comprehensive Complication Index & -0.289 & $\mathbf{0 . 0 0 3}$ \\
\hline Modified Frailty Index & -0.221 & $\mathbf{0 . 0 2 7}$ \\
\hline POSSUM morbidity score & -0.324 & $\mathbf{0 . 0 0 1}$ \\
\hline POSSUM mortality score & -0.322 & $\mathbf{0 . 0 0 1}$ \\
\hline ACS-NSQIP score & -0.128 & 0.206 \\
\hline ACS-NSQIP excess score & -0.175 & 0.082 \\
\hline Comprehensive Complication Index & -0.328 & $\mathbf{0 . 0 0 1}$ \\
\hline Modified Frailty Index & -0.189 & 0.06 \\
\hline POSSUM morbidity score & -0.29 & $\mathbf{0 . 0 0 3}$ \\
\hline POSSUM mortality score & -0.289 & $\mathbf{0 . 0 0 3}$ \\
\hline ACS-NSQIP score & -0.14 & 0.165 \\
\hline ACS-NSQIP excess score & -0.164 & 0.104 \\
\hline Comprehensive Complication Index & -0.327 & $\mathbf{0 . 0 0 1}$ \\
\hline
\end{tabular}

